\title{
Web-Based Information System of Sundutan Tigo Village Budget and Revenue, Mandailing Natal Regency
}

\author{
Tonni Limbong ${ }^{1}$, Zecrin Damai Harefa ${ }^{2}$ \\ ${ }^{12}$ Universitas Katolik Santo Thomas Medan, Jl. Setiabudi No. 479 F Tanjungsari, Medan, Indonesia
}

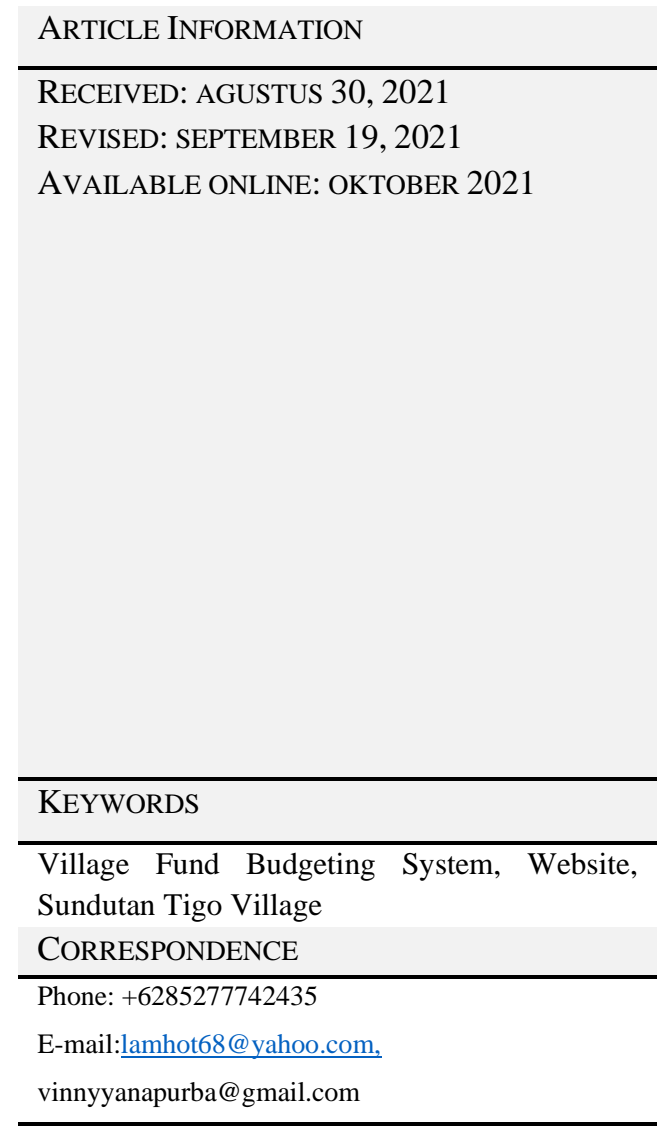

\begin{abstract}
A B S T R A C T
The digital village is a community empowerment program through the use of digital technology and the internet in developing village potential, marketing and accelerating access and information services. The Sundutan Tigo Village Office is a government agency, having its address at Sundutan Tigo Village, Natal District, Mandailing Natal Regency. The Village Office has the receipt and disbursement of funds. Based on the results of the pre-survey at the research location, there are still many people who do not know how much the village fund budget is realized by their village government per year. In fact, in this case the main purpose of rolling out village funds is other than for rural development, the most important thing is how the village government empowers village communities, so that they can support national development through work carried out in villages both from an economic and other perspective. etc. For this reason, a computerized information system is needed, which is able to overcome the obstacles and problems that exist in the transparency of the village fund management.
\end{abstract}

\section{INTRODUCTION}

The digital village is a community empowerment program through the use of digital technology and the internet in developing village potential, marketing and accelerating access and information services. The digital village allows the community in the village in question to more easily access information about the law, including statutory regulations. This means that the existence of a digital village actually opens up more opportunities to optimize the dissemination of laws and regulations more evenly. Thus, the existence of a digital village actually also has a positive influence on law enforcement efforts in Indonesia [1].

The Village Fund according to the village fund pocket book issued by the Ministry of Finance (2017) is the State Revenue and Expenditure Budget funds used for Villages that are sent for the implementation of development and community empowerment through the district/city Regional Revenue and Expenditure Budget. Allocation of Village Funds according to Article 1 Paragraph 11 of PP Number 72 of 2005 is the allocation of funds by the Regency/City Government for the Village, and sourced from the central and regional finances used by the Regency/City [2].

The Sundutan Tigo Village Office is a government agency, having its address at Sundutan Tigo Village, Natal District, Mandailing Natal Regency. The Village Office has the receipt and disbursement of funds. Village Funds are funds sourced from the APBN which are intended for villages which are transferred through the Regency/City APBD and are used to finance government administration, development implementation, community development, and community empowerment. However, the allocation of funds given usually has become a tradition for antagonist actors in the government to misuse the funds supplied from the government, there are elements of the village apparatus who deliberately allocate funds inappropriately, then minimize the targeted budget and cut funds. issued, such things are certainly common in this country, so that deviant actions need to be watched out for, and anticipated, because these actions will harm and also hinder progress and also have an effect on the village itself, food for the family should not be consumed with the heart alone. 


\section{METHOD}

The stages in this research are:

1. Literature study This writing begins with a literature study, namely collecting reference materials from books, journals, papers, and internet sites regarding Information Systems for Budget Management and Revenue Expenditures in Sundutan Tigo Village.

2. Software analysis and design Analyze existing problems, limitations and requirements needed. After that do the system interface design.

3. Implement and test the system Implement interface design and testing of the built system and test the results.

\section{Problem Analysis}

\section{RESULTS AND DISCUSSION}

The ongoing system analysis will discuss the procedures for managing village funds in Sundutan Tigo Village. Document analysis is the decomposition of a system with the intention of identifying existing documents on the system that is running. Document analysis can be seen in the following.

\begin{tabular}{|l|l|l|}
\hline No. & Document & Description \\
\hline 1 & Data Archives / Receipts & $\begin{array}{l}\text { Contains data on the management of village funds and receipts of village } \\
\text { fund expenditures }\end{array}$ \\
\hline 2 & $\begin{array}{l}\text { Report on the realization of the use } \\
\text { of village funds }\end{array}$ & Contains reports on the use of village funds for stages I and II \\
\hline 3 & Village wealth report Contains & village assets or property from the village's original wealth \\
\hline 4 & Financial report (LPJ) & Contains accountability reports (income and expenditures) etc. \\
\hline
\end{tabular}

Source: (Office of the Head of Sundutan Tigo Village, 2020)

\section{Design}

Based on the current system, it is known that the old system still cannot meet the needs in data processing quickly and precisely. After the system requirements are known, the next step is to design a proposed system design that aims to meet the needs that are not obtained from the existing system. an overview of the designed system is presented in UML (Unified Modeling Language). With UML (Unified Modeling Language) logically, the system requirements, as well as the entities involved in the designed system, can be known. The following is the design of a Web-Based Village Fund Transparency Information System in Sundutan Tigo Village.

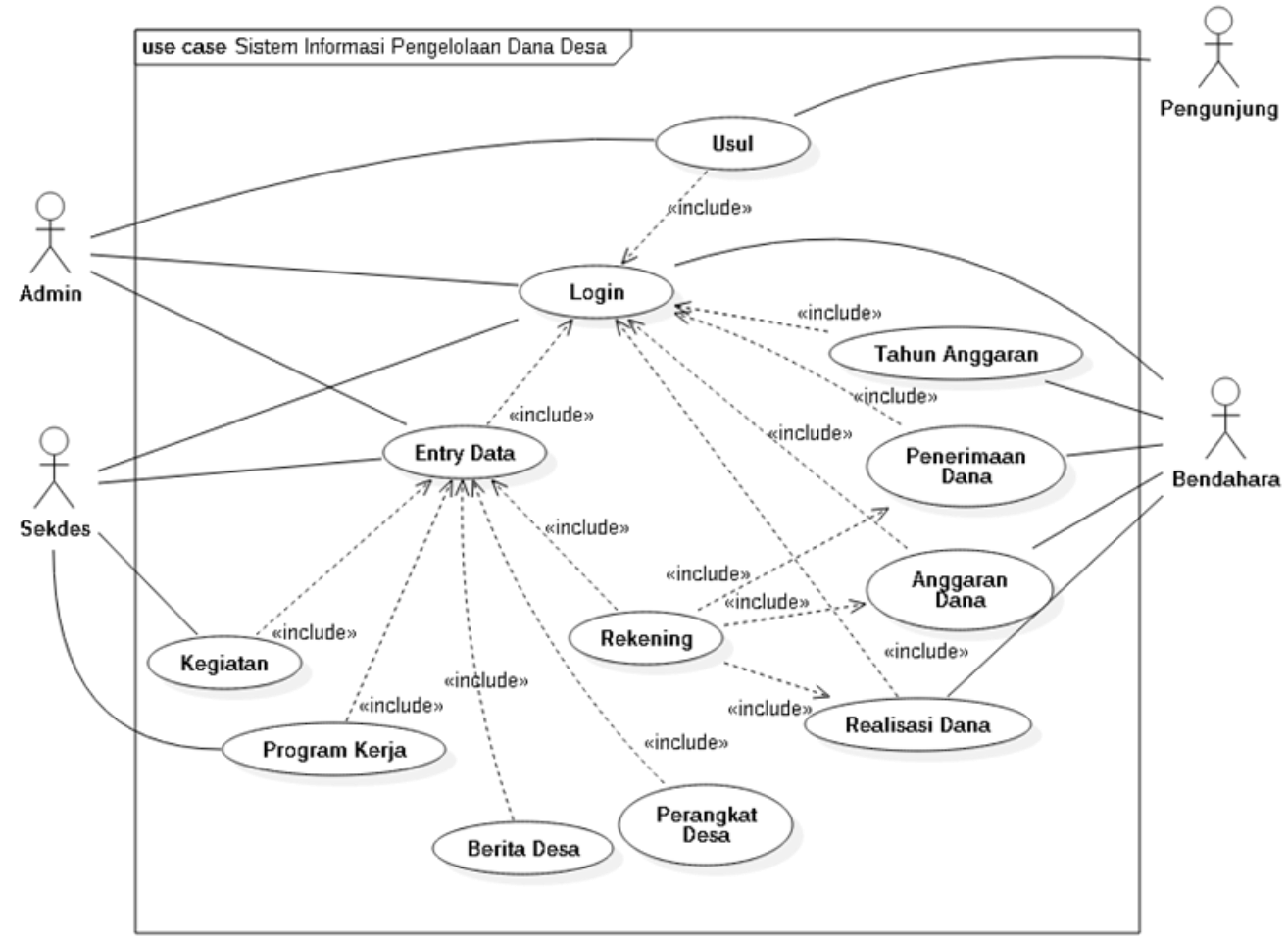

Figure 1 Use Case Diagram 


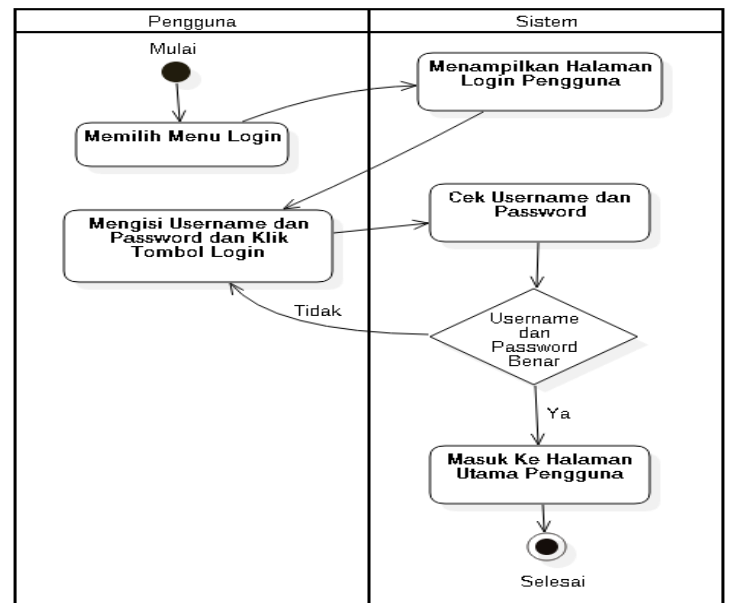

Figure 2 Activity Diagram

The main page is the initial display when the system is running, where on the main page there are many choices of links that are useful for moving from one page to another. On the main page, information about the village finances of the village work program and news information about the village of Sundutan Tigo is also displayed. The form of the main page display for general visitors can be seen in Figure 3.

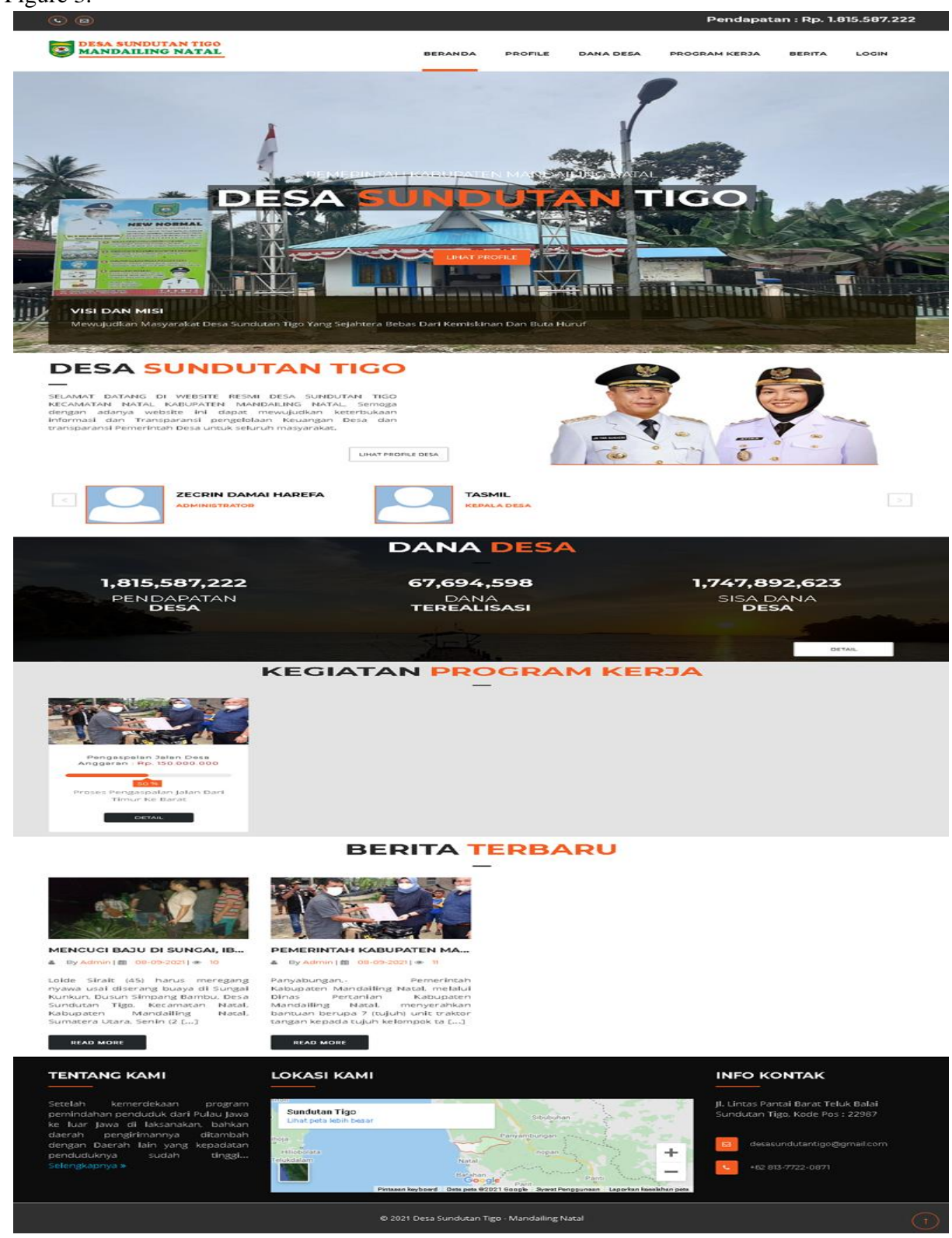

Figure 3 System Main Page

Web-Based Information System of Sundutan Tigo Village Budget and Revenue, Mandailing Natal Regency 
The village fund page serves to present village fund information consisting of village fund income, village fund realization and village fund budget. The view of the village fund page can be seen in Figure 4 .

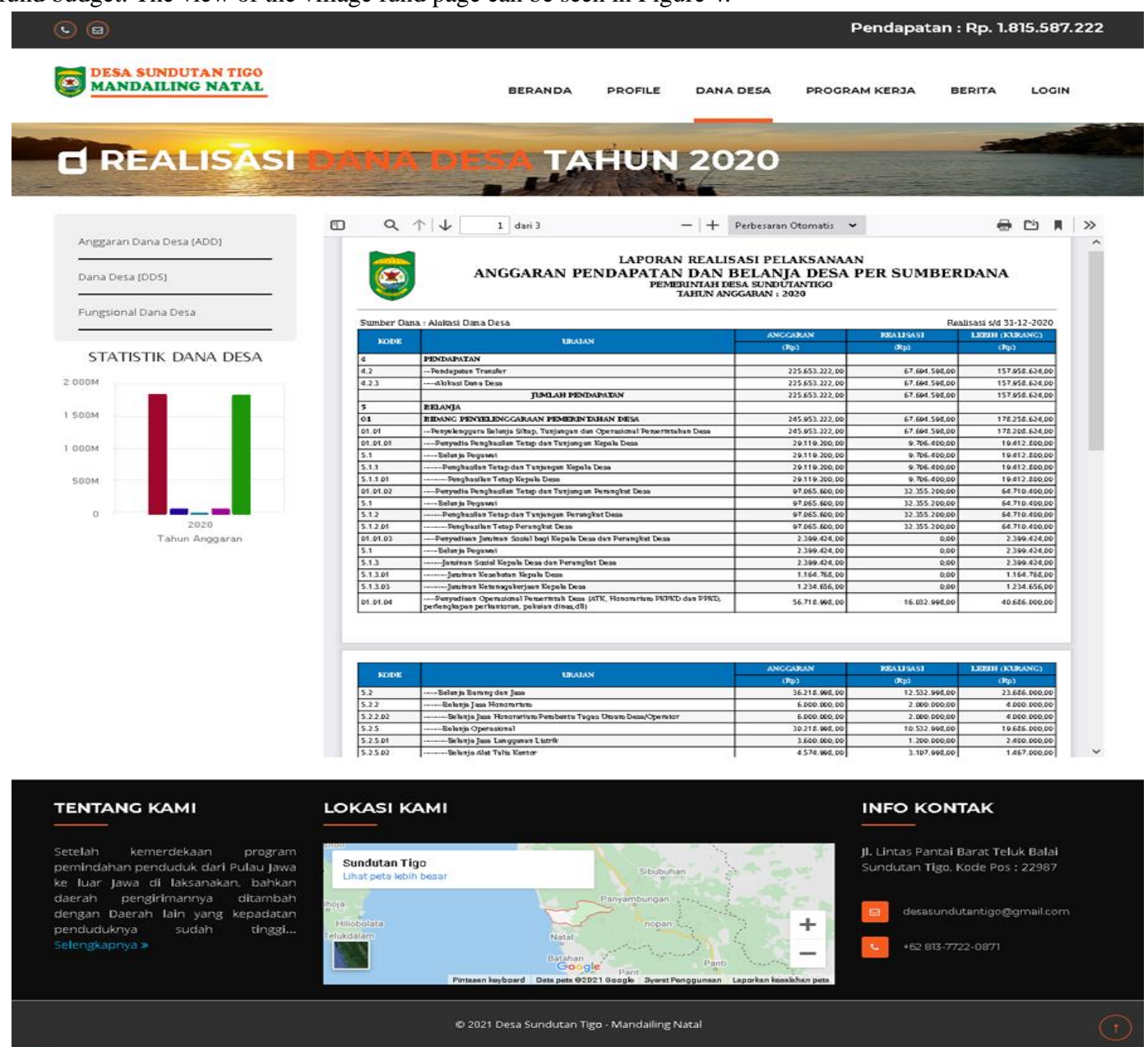

Figure 4. Village Funds Page View

This interface serves to validate account access before entering the system user page. On the login page there is a username and password field that must be filled in correctly by the user. The display of the user login page can be seen in Figure 5

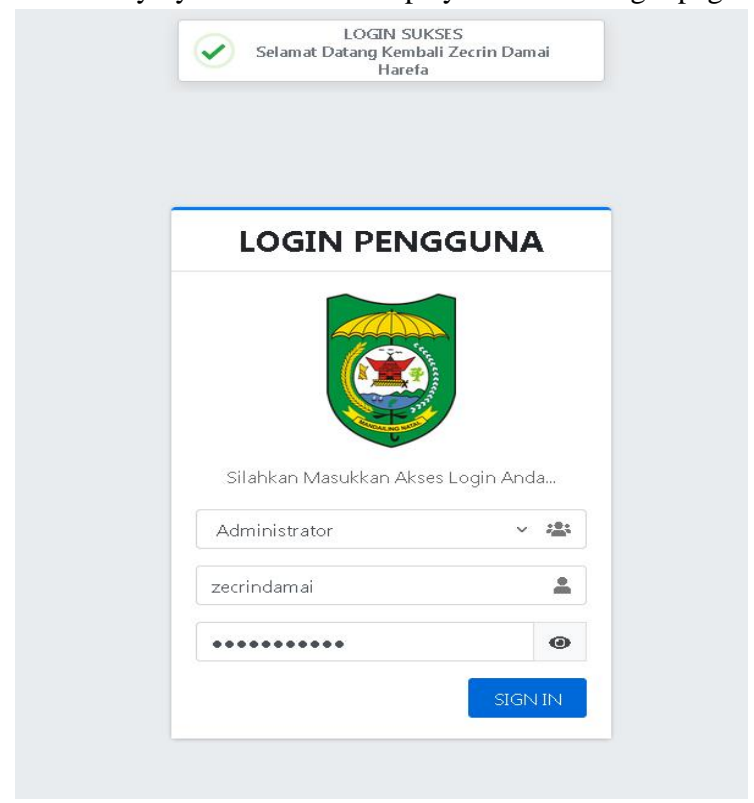

Figure 5. User Login Page Display

The main user page is one of the pages that will be generated on the system to be built. The user page functions to process village financial data. The display of the user's main page can be seen in Figure 6 


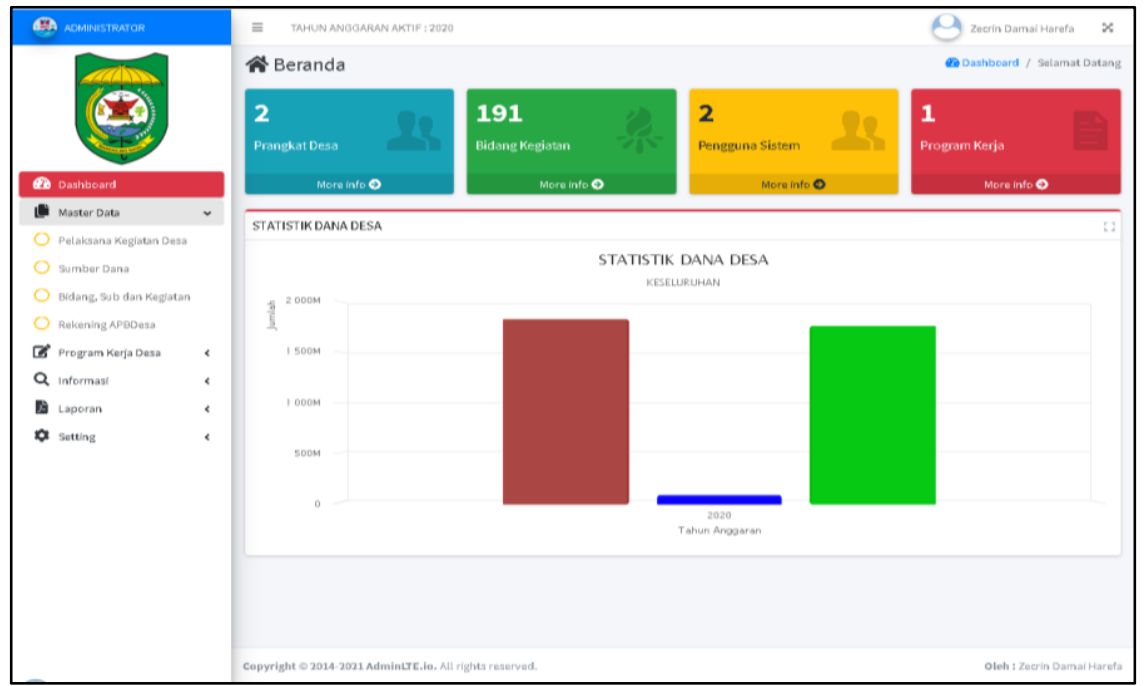

Figure 6. User Main Page Display

\section{CONCLUSIONS}

After completing the design of an information system on the use of village funds in the web-based sundutan tigo village, it can be concluded that:

1. The design of an information system on the use of village funds has been successfully made. At the analysis stage, the tools used for modeling are UML (Unified Modeling Language), Use Case Diagrams, Activity Diagrams, Sequence Diagrams and Class Diagrams. The design stage is carried out.

2. Analysis of the design of the information system on the use of village funds through the use case diagram that is produced providing facilities for using applications in village receipts and funds.

3. Analysis of information system design using village funds provides an alternative for users to be able to complete their work using a computerized system.

4. With the system built, the community can find out the use of village funds quickly, because the system that has been built has provided information about the village fund budget and the use of village funds according to the current budget year.

5. With this new system, it can speed up and simplify report generation compared to the current system

\section{REFERENCES}

[1] E. Wijaya, R. Anggraeni, and D. R. Bachri, "Desa Digital: Peluang Untuk Mengoptimalkan Penyebarluasan Peraturan Perundang-undangan di Indonesia," J. Din. Huk., vol. 13, no. 1, pp. 75-88, 2013, doi: 10.20884/1.jdh.2013.13.1.158.

[2] B. Boedijono, G. Wicaksono, Y. Puspita, S. C. Bidhari, N. D. Kusumaningrum, and V. Asmandani, "Efektifitas Pengelolaan Dana Desa Untuk Pembangunan Dan Pemberdayaan Masyarakat Desa Di Kabupaten Bondowoso," J. Ris. Manaj. dan Bisnis Fak. Ekon. UNIAT, vol. 4, no. 1, pp. 9-20, 2019, doi: 10.36226/jrmb.v4i1.237.

[3] B. Bruegge and A. H. Dutoit, Object-Oriented Software Engineering Using UML, Patterns, and Java ${ }^{T M}$, Third., vol. 821 LNCS. Munich: Prentice Hall, 2010.

[4] J. Chan, Learn Python in one day and learn it well: Python for beginners with hands-on project: the only book you need to start coding in Python immediately. 2016.

[5] A. Dennis, B. H. Wixom, and D. Tegarden, Systems Analysis \& Design An Object-Oriented Approach with $U M L$, Fifth. United States of America: John Wiley \& Sons, Inc. All, 2015.

[6] L. Lemay, R. Coburn, and J. Kyrnin, SamsTeachYourself HTML, CSS \& JavaScript Web Publishing in One Hour a Day, Seventh., vol. 7. United States: Pearson Education, Inc., 2016.

[7] H. G. Molina, J. D. Ullman, and J. Widom, Database Systems The Complete Book, Second. New Jersey: Pearson Education, Inc., 2009.

[8] R. Rauf and S. Maulidiah, Pemerintahan Desa. Yogyakarta: Zanafa PubLishing, 2015.

[9] R. Scott, PHP MySQL PHP Programming Guide Web Development, Database Hacking. 2018.

[10] M. Seidl, M. Scholz, C. Huemer, and G. Kappel, UML@Classroom: An introduction to object-oriented modeling, vol. 1555. Switzerland: Springer, 2015.

[11] G. Y. Swara and Y. Pebriadi, "Rekayasa Perangkat Lunak Pemesanan Tiket Bioskop Berbasis Web," J. TEKNOIF, vol. 4, no. 2, pp. 27-39, 2016.

[12] T. TEOREY, S. LIGHTSTONE, T. NADEAU, and H. V. JAGADISH, Database modeling and design : logical design, Fifth., vol. 66. Amsterdam: Elsevier, 2011. 